\title{
The Practice of Sale and Purchase and Ownership of Right to Agricultural Land by Civil Servant
}

\author{
I Harianti $^{*}, 1$ and Suyatno ${ }^{2}$ \\ Department of Law, Universitas Maarif Hasyim Latif, Indonesia ${ }^{1,2}$ \\ \{isnin-harianti@fh.umaha.ac.id $\left.{ }^{1}\right\}$
}

\begin{abstract}
The purpose of this research is to enable civil servants in Indonesia to do legal deeds and obtain rights to agricultural land (absentee) in Indonesia, which according to the laws and regulations of the land agriculture is prohibited to be traded by residents who live outside the object sub-district is located. The applied research method is empirical normative. Data were obtained from field studies in both the agricultural land area and the local Land Office. This method is a combination of normative legal approach with the addition of various empirical elements of the implementation of normative law provisions (laws) with certain legal acts that occur in society. This research was conducted in Argosari Village, JabungSubdistrict, Malang Regency, East Java Province. Where found the practice of buying and selling conducted by Civil Servants who are domiciled in the Capital Jakarta. To be able to carry out legal acts of buying and selling and obtaining rights to the agricultural land, Civil Servants who want to perform legal acts that must meet the requirements and binding provisions of the Land Office of Malang Regency. The results showed that Civil Servants could perform legal acts of buying and selling and obtaining rights to the agricultural land until the issuance of Certificate of Own Right by making a Statement Letter addressed to the Head of Land Office of Malang Regency. This research is a real solution and proof that Civil Servant can do legal action of sale and purchase and get rights to farmland (absentee).
\end{abstract}

Keywords: Land Ownership, Absentee, Agricultural Land, Land Rights

\section{Introduction}

Indonesia is an agrarian country. The majority of the livelihoods of Indonesians are farmers. The agricultural sector has an important role in maintaining the food security of this country. To keep the farmland from declining in terms of breadth, the ban on the sale and purchase of agricultural land is enforced. Article 33 Paragraph (2) of the 1945 Constitution of the State of Indonesia states: "The earth, water and natural resources contained therein are controlled by the State and used for the greatest prosperity of the people. This indicates that the State controls and regulates agriculture [1]. The ban on buying and selling of agricultural land is carried out in this country. The prohibition against the sale of agricultural land or absentee includes the traders, the maximum amount of land traded, and the rights to agricultural land or absentee obtained after sale and purchase must still be used for agricultural land. Indonesia itself has a special regulation governing the land of Law No. 5 of 1960 on 
Basic Agrarian Law (UUPA), which came into effect on September 24, 1960 [2], [3], [4]. One of the important legal aspects of the enactment of the UUPA is the launching of the "Land reform Program" in Indonesia aimed at enhancing the income and living standards of the tiller farmers, as a basis or prerequisite for organizing economic development towards a just and prosperous society based on Pancasila (Nation Fundamental). One of the land reform programs is the prohibition of absentee/guntai land ownership, which stems from the legal basis of Article 10 UUPA [5], [6].

The definition of Landreform in Indonesia is divided into two parts:

1. Land reform in a broad sense, the term Agrarian Reform Panca(Five) Program, consisting of:

- Renewal of Agrarian Law.

- Abolition of foreign rights and colonial conceptions of land.

- Put an end to the feudal exploitation gradually.

- Reformation of land ownership and control and legal relations of land tenure concerned with

- Planning, inventory, designation, and use of the earth, water and wealth contained therein and, its use in a manner consistent with its power and capabilities and capabilities.

2. Land reform in a narrow sense, concerning the reformation of land ownership and control as well as legal relations with respect to land tenure [6], [7]. The Land reform Program includes:

- Limitations on the maximum land tenure.

- Prohibition of ownership in absentee.

- Redistribution of the remaining lands to the maximum, absentee lands, swapraja lands and state lands.

- Arrangement on the return and redemption of agricultural land which is mortgaged.

- The reorganization of agricultural land revenue sharing agreements, and

- Determination of a minimum area of agricultural land ownership with the prohibition to perform acts that resulted in splitting the ownership of agricultural lands into parts that are too small [6], [7].

With the enactment the program of land reform, then there is a ban on the sale and purchase of agricultural land, furthermore regulated in:

1. Article 7 of Law No. 5 of 1960 on the Basic Regulations of Agrarian Principles which reads: "To not harm the public interest, the ownership and control of land which exceeds the limit is prohibited. "(Law of the Republic of Indonesia No. 5 of 1960 1960).

2. Article 10 of Law No. 5 of 1960 on the Basic Regulations of the Agrarian Principles: "Any person or legal entity having a right to agricultural land on its principle is required to work on or actively work on it by preventing extortion measures. "(Law of the Republic of Indonesia no. 5 years 1960 1960).

3. PP No. 224 of 1961 amended and supplemented by Government Regulation No. 41 of 1964 concerning the Implementation of Land Distribution and Displacement states:

Law Article 3:

- Owners of land residing outside the sub-district where the land is located shall within six months transfer the right to his / her land to another in the sub-district where the land is located or moved to the sub-district where the land is located. 
- The obligations referred to in paragraph 1 of this article shall not apply to landowners residing in sub-districts adjacent to sub-districts where the land is located, if the distance between the owner's residence and the land is still possible to work the land efficiently, according to the consideration of the Regional Level Land Reform Committee.

- Without prejudice to the provisions of paragraph 2 of this article, if the landowner moves to or leaves his residence outside the sub-district where the land is located for two consecutive years, he shall transfer his land title to another resident in the subdistrict that.

- The provisions of paragraphs 1 and 3 of this Article shall not apply to those who have landed in their homes or districts as meant in paragraph 2 of this article, who are carrying out the duties of the State, performing religious duties, or having other acceptable special reasons by the Minister of Agrarian Affairs. For civil servants and military officers and those equal to those exercising the duties of the State, the exceptions referred to in this paragraph shall be limited to the possession of agricultural land up to $2 / 5$ of the maximum area specified for the territory in accordance with the Act Number 56 Prp Year 1960.

- If the obligations referred to in paragraphs 1 and 3 of this Article are not met, the land concerned shall be taken by the Government, then distributed according to the provisions of this Regulation.

- To the former landowners referred to in paragraph 5 of this article shall be compensated according to the provisions of this Regulation (Law, Public Relations, and Law 1960).

4. Article 17 paragraph 3 of Law Number 5 Year 1960 on the Basic Regulation of Agrarian Principles states: " The lands which are excess of the maximum limit referred to in paragraph (2) of this article shall be taken by the Government with compensation for further distribution to the people in need under the provisions of the Government Regulation. "(Law of the Republic of Indonesia No. 5 year 1960 1960).

Although there are many regulations that prohibit and restrict the sale of land purchase land or absentee, the sale of land is still an exception, which is allowed. Agricultural land or absentee can be sold to Civil Servants, as set forth in Article 2 paragraph (1) of Government Regulation No. 4 of 1977 concerning Absentee Land Ownership for Retired Civil Servants, which states:Since the coming into effect of this Government Regulation, the exemption from the provisions concerning the prohibition of possessing farmland in the absentee manner applicable to public servants as regulated in Article 3 of Government Regulation No. 224/1961 (Statute Book of 1961 No. 280) jo. Government Regulation Number 41 of 1964 (State Gazette Year 1964 Number 112) to the limit of 2/5 (two fifths) of the maximum landholding for the Level II Regions concerned shall also be treated for:

- Retired civil servants and

- Widows of civil servants and widows of retired civil servants as long as not remarry with a non-public servant or a retired civil servant.

Anyone referred to as the Civil Service is governed by article 1 of the Government Regulation of the Republic of Indonesia Number 4 of 1977 concerning Absentee Land Ownership of Land for Retired Civil Servants, which states: "Referred to as" civil servant "in Government Regulation these are those classified as civil servants as referred to in Law Number 8 of 1974 on the Principles of Personnel at the Directorate General of Legislation (State Gazette Year 1974 Number 55, Supplement to the State Gazette Number 3041). 
"(www.djpp.depkumham .go.id 1977).More on who the Civil Service is meant to be in Article 1 letter (a) of Law Number 8 Year 1974 is updated by Law Number 43 of 1999, on the Principles of Personnel, which states: "Public Servants are those who after fulfilling the conditions stipulated in the applicable laws and regulations, shall be appointed by the competent authority and assigned the duties of any State office or assigned to the duties of the other State stipulated in accordance with legislation and salaried according to the prevailing laws and regulations."

Article 2 paragraph (1) and (2) of Law No. 8 of 1974 on the Principles of Personnel, which states:

1. Public servants consist of:

- Civil Servants, and

- Member of the Armed Forces of the Republic of Indonesia.

2. Civil Servant consists of:

- Central Civil Servant;

- Regional Civil Servant; and

- Other Civil Servants stipulated by Government Regulation (No Title 1999).

Agricultural land or absentee in Argosari Village, Jabung District, Malang Regency, East Java Province is very wide. In this study, found the practice of buying and selling agricultural land that is done by Civil Servants (not yet retired or still serving). Civil Servants are domiciled in the Capital Jakarta. This is indicated from the documents of the terms of sale and purchase, namely Identity Card, Family Card, and Marriage Book [6], [8]. The Sale and Purchase Transaction between the Civil Servant and the farmer of the farmer land was done in front of PPATS (Temporary Land Deed Officer), who was then the Camatof Jabung, and witnessed by the Village Head and Argosari Village Officer. Then, to obtain the recognition of the land rights, evidence of transfer of sale and other supporting documents is used as a requirement of the land rights application at the Land Office of Malang Regency [7], [9], [10]. In the process, the Land Office of Malang Regency provides binding terms and conditions to the Civil Affairs Employee. The practice of buying and selling, technical steps, and requirements will be explained further on the results of this.

\section{Method}

This research method is empirical, normative research method which is a combination of prescriptive law approach with the addition of various practical elements. The practical normative research method concerning the implementation of normative legal provisions (laws) in its action on specific legal acts that occur in society [11]. The type of research conducted is research in the field, which is done in detail and depth of the object to be studied the absentee land in the District Jabung, Malang Regency, East Java Province. The nature of this study is qualitative that does not use the figures but based on legislation and data processing is descriptive-analysis. This research describes, analyze, explains, and analyze the law both in the form of theory and practice of implementation of research result in the field, which in the enforcement of the prohibition of absentee land ownership in DistrictJabung, Malang Regency there are also exceptions for civil servants domiciled outside DistrictJabung. 


\section{Result and discussions}

The results showed that farmland or absentee could be traded by Civil Servant, who have not retired or full of duty, even those who live far from the sub-district where the land of agricultural land is located. The practice of buying and selling is done by Civil Servant and Farmer of the agrarian landowner in front of PPATS Notary of Malang Regency, that is JabungCamat, witnessed by Head of Village and some of Argosari village equipment. Both the Seller and the Buyer, each submitting the administrative requirements of the sale and purchase of the Identity Card, Family Card, Marriage Book, SPPT PBB of the current year, and a copy of letter $\mathrm{c}$ and land history issued by the Head of Argosari Village, Jabung Subdistrict, Malang Regency. After the sale and purchase transition, the process revolved in the Land Office of Malang Regency to reverse the name and application of the land rights. In the process of this petition, the Land Office of Malang Regency provides binding terms and conditions for the Civil Servant. One of them to obtain the right to his land, he must make a statement under enough stamped hands, known by the Head of Argosari Village. That after he retired from his duties as a Civil Servant, he will return and reside in his homeland, Malang Regency, willing to become a farmer, working on the farm, nor do they change the condition of the soil from agricultural land to yard or else

The process of land rights application in Malang Regency, rolling start Process Measurement, field map, Adjudication committee, announcement during two months at Argosari Village Office, until the issuance of Certificate of Property on behalf of the Civil Servant. The length of the measurement process until the publication of Certificate of Property on behalf of the Civil Servant is a maximum of 12 months. This is due to the long queue at the Land Office of Malang Regency. can be shown with a scheme in figure 1.

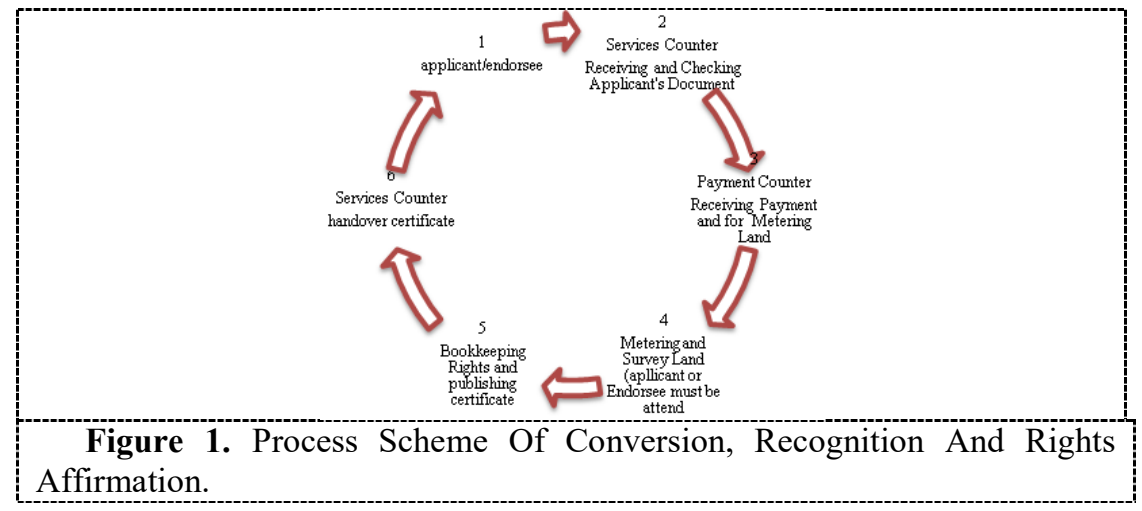

\section{Conclusions}

Notwithstanding the prohibition of the sale and purchase practices of absentee or agricultural land in accordance with Law No. 5/1960 on Basic Agrarian Principles (UUPA), but there are exemptions or permissible sale and purchase, as in Article 1 of Government Regulation No. 4 the Year 1977 Concerning the Land Ownership of the Land of the Empire (Absentee) for Retired Civil Servants. But research shows that Civil Servants can practice buying and selling land absentee or agricultural land. The research was conducted in Argosari village, Jabung sub-district, Malang regency. A civil servant who is still active in the service 
and who is domiciled in the sub-district of the absentee land is located, must make a statement made under special-duty hand, known to the Head of Argosari Village, that the Civil Servant is willing to return to Argosari village, ready to become a farmer to manage the farm. The results prove that civil servants get the rights to absentee land or agriculture. Although the civil servant is domiciled far outside the district where the object is located and has not retired. Binding requirements are given by the Land Agency of Malang Regency. The conditions are included in the requirements for the absentee or agricultural land title application. Land rights application process starts from measurement, field map publication, adjudication committee, announcement in Argosari village for 2 months. This process lasts for approximately 12 months. This research provides benefits and is a solution for civil servants and retired civil servants to be able to conduct trade and purchase and obtain the rights to absentee or agricultural land.

\section{References}

[1] J. Alcamo, Ecosystems and human well-being: a framework for assessment. Washington DC: Island Press, 2003.

[2] Nasrianti, "Kewenangan Pemberian Persetujuan Dan Perizinan Penanaman Modal Menurut Undang-Undang No. 25 Tahun 2007 Tentang Penanaman Modal (Studi Di Provinsi Nanggroe Aceh Darussalam)," Universitas Sumatera Utara, 2007.

[3] E. K. Dewi, Sudjito, and S. H, Peran kantor pertanahan dalam mengatasi kepemilikan tanah absentee di Kabupaten Magelang. Yogyakarta: Universitas Gadjah Mada, 2010.

[4] Usman, "Eksistensi Kekayaan Negara Yang Dipisahkan Dalam Lembaga Penjamin Simpanan Sebagai Badan Hukum,” J. Cita Huk., vol. 5, no. 1, pp. 115-38, 2013.

[5] A. A. Astutiningsih, "Peran Kantor Pertanahan Terhadap Pelaksanaan Larangan Kepemilikan Tanah Secara Absentee/Guntai Di Kabupaten Sukoharjo,” J. Reper., vol. 5, no. 1, 2018.

[6] I. G. N. Agung, "Tinjauan Kritis atas Peraturan Perundang-Undangan Landreform (Batas Maksimum, Minimum dan Absentee) dalam Rangka Penyempurnaan UUPA/Pembaruan Agraria," Kertha Patrika, vol. 34, no. 1, pp. 65-77, 2010.

[7] E. Y. S. Tolo, "Reforma Agraria dan Aliansi Kelas Pekerja di Indonesia," J. Ilmu Sos. dan Ilmu Polit., vol. 16, no. 3, pp. 234-249, 2013.

[8] A. Dewi, Peran Kantor Pertanahan Dalam Mengatasi Kepemilikan Tanah "Absentee/Guntai" Di Kabupaten Banyumas (The Role Of The Agrarian Office In Overcoming “ Absentee/Guntai” Land Ownership In Banyumas Regency). Semarang: Program Pascasarjana Universitas Diponegoro, 2008.

[9] S. A. Hamid, "Faktor-Faktor yang Berpengaruh terhadap Terjadinya Tanah Absentee dan Dampaknya bagi Masyarakat di Kecamatan Binuang Kabupaten Polewali Mandar Pepatudzu," Media Pendidik. dan Sos. Kemasyarakatan, vol. 8, no. 1, pp. 94-108, 2016.

[10] W. Harsono, Peran Kantor Agraria dan Tata Ruang/Badan Pertanahan Nasional Kabupaten Kudus dalam Mengatasi Kepemilikan Tanah 'Absentee/Guntai. Kudus: Fakultas Hukum UNISSULA, 2016.

[11] A. P. Parlindungan, Undang-undang bagi hasil di Indonesia: suatu studi komparatif. Bandung: Mandar Maju, 1989. 